\title{
Digital Media Development of Math Game with Ethnomathematics Model Based on Javanese Local Wisdom in Higher Education
}

Buchori A*, Sudargo, Rahmawati ND and Budiman MA

Study of Mathematics Education, University PGRI Semarang, Kota Semarang, Indonesia

"Corresponding author: Buchori A, Study of Mathematics Education, University PGRI Semarang, Kota Semarang, Indonesia, Tel: +62248316377; E-mail: buccherypgri@gmail.com

Received date: August 04, 2016; Accepted date: August 22, 2016; Published date: August 26, 2016

Copyright: (c) 2016 Buchori A, et al. This is an open-access article distributed under the terms of the Creative Commons Attribution License, which permits unrestricted use, distribution, and reproduction in any medium, provided the original author and source are credited.

\begin{abstract}
The purpose of this study is to produce products such as digital applications of math games on mobile phones and digital applications of math games on the computer at the high school math courses that is valid used in mathematics education program at the University of PGRI Semarang and Semarang Sultan Agung Islamic University. This research method used development model of Borg and Gall which includes 10 steps, namely (1) Research and information collecting, (2) Planning, (3) Develop a preliminary form of the product, (4) Preliminary field testing, (5) Main product revision, (6) Main field testing, (7) Operational product revision, (8) Operational field testing, (9) Final product revision, (10) Dissemination and implementation. From the results of over two years, the data showed that digital media of math game has been valid that is validated by experts at an average of $85 \%$, then gets the user response in University PGRI of Semarang and Semarang Sultan Agung Islamic University, namely $76.5 \%$, and the mean average results of student learning at the University PGRI of Semarang and Semarang Sultan Agung Islamic University are 84.5 and 83.33 . From percentage of expert validation results, the user response and the results of student learning, the digital product of math game is declared valid, practical and effective used in the process of mathematics learning in college.
\end{abstract}

Keywords: Digital Math Game; Ethnomathematics; Senior High School; Mathematics

\section{Introduction}

The development of ICT IS very rapidly this decade, it should be taken seriously in order to bring a positive impact in print prospective educator who is professional and has good characteristics. Concrete steps done by the University PGRI of Semarang and Semarang Sultan Agung Islamic University in facing this challenge are as follows: (1) providing computer labs in each study program, (2) completing a computer device in the form of hardware and software in every classroom, (3) conducting training for lecturers to be able to master ICT in learning in a good and right manner. But in reality there is still a few of lecturer who apply ICT in the learning process. Based on data from interviews with several professors of mathematics in University PGRI of Semarang and Semarang Sultan Agung Islamic University, it found that students' interest in the subject of High School Mathematics is still low, it is because the lecturers have not been able to pack maximum learning, especially in using math hardware and software. Low interest can make learning becomes less than optimal. This is because students are less active for participating in the learning process. Interactive and fun learning media can increase student interest in learning [1]. The technology that is now developing can support the independent learning process, one of them is computer.

Computers can be used as a medium of learning. According to Wankat and Oreonovicz, as cited by Wena [2], one of the advantages of learning by using computer as learning media is to stimulate students to do the exercise because of the availability of (1) graphics animated, (2) color, and (3) music. Computer, notebook, or laptop is not a luxury item anymore, so a lot of people who already have a computer.
Therefore, a computer learning media can facilitate students to learn independently. Students can learn to use a computer either on campus or at home. Game is one thing that is liked by children. With the development of the existing technology then comes the computer game. In the computer game, there are several elements that can drive a person to linger to play. These elements of which are a great view, great content, and joy when completing a level or stage to get to the next level.

In the e-book "Learning in Immersive worlds A review of gamebased learning", Sara de Freitas [3] explains some of the functions of the game, namely: (1) to motivate and engage learners in learning activities (2) to train skills or assignment (3) to provide therapy to relieve pain and cognitive difficulties (4) to play the role of a particular job and profession prior to practice in real life (5) to empower learners as a writer and producer of multimedia, mixed media and contentbased games. Then clarified by Burguillo [4] on 'Using game theory and competition based learning to stimulate student motivation and performance Computers \& Education' shows that the presence of the game in learning makes students motivated and their computer capability increases. Then in this case it needs to be done planting local culture associated with math, Muhammad [5] explains that the local culture that is packed with digital computers make students understand and get to know the local culture easily. Then amplified by Hwang and $\mathrm{Wu}[6]$, which indicates the digital game based learning from 2001 to 2010 rise in the British territory. Then amplified by Ebner and Holzinger [7], which explains that a computer based educational game can increase student interest in learning. Further educational games can also improve motivation to learn [8], so Garris [9] proved if Games with mobile can make student have more motivation at learning any lesson. And then Cheng et al. [10], showed student made high motivation, Engagement and Learning through Digital Games, 
basic statement Panoutsopoulos [11] showed A Study on Exploiting Commercial Digital Games into School Context more positive effect to student and Kebritch [12] proved the pedagogical foundations of modern educational computer games more effective and make student happy.

Based on these descriptions, then the problem can be formulated as follows: (1) how to develop digital media of math game with ethnomathematics model with the javanese local wisdom based that is valid used at the University of PGRI Semarang and Semarang Sultan Agung Islamic University? and (2) whether the learning with the use of digital math game with the ethnomathematics model with javanese local wisdom -based can take place effectively and practically?

\section{Theory Review}

\section{Media digital math game}

Computers as electronic media, today have a variety of functions. Some of the benefits of the computer are typing, editing a song, image and communication. Computers also have benefits in the field of education, namely as a medium of learning. Some functions of computer-based learning media according to Wena [2] are an exercise, tutorials and simulations.

Digital game is one of the interactive media used by children as a means to learn and play [5]. A game is liked by children. Children prefer to spend hours and hours to play than to study. Now this game is already in electronic media thus now known the term computer games and online games. Not only children who love the game but teens and adults also love it. Therefore, the game can be used as a tool for learning. This is done by inserting the learning materials inside the game or combining them.

In use, not all games can be used as teaching material, in this case is the medium of learning. There are several things to consider when developing the game as a teaching material. Based on "Learning Material Development Guide", Ministry of Education explains that there are four evaluation components for teaching materials that have been developed. These components are, namely (1) the feasibility of content, (2) linguistic, (3) serving, and (4) graphs.

\section{Ethnomathematics model}

Shirley [13], argued that the present ethnomathematics field, namely mathematics that arise and grow in the community and in accordance with the local culture, is a center of learning and teaching methods. This opens up the pedagogical potential that consider the students' knowledge gained from learning outside the classroom. Mathematics essentially grew out of the skill or activity in cultural environment [14], so that someone's mathematics influenced by his cultural background. Mathematics growing within the community is called ethnomathematics by the Bishop. "Ethnomathematics in the elementary classroom is where the teacher and the student's value cultures, and cultures are linked to curriculum". Ethnomathematics is a complex and dynamic representation that describes the cultural influence of the use of mathematics in their applications.

\section{Research Method}

\section{Location and time of research}

- Location
Locations of the study are at the University PGRI of Semarang and Semarang Sultan Agung Islamic University.

- Research time

Time of the study is started at the beginning of the school year 2015-2016 for approximately 2 years.

\section{Research subject}

According Tuckman [15] to choose subject can use stratified random sampling any private university in Semarang, the population in this study were all students of fourth semester of Mathematics Education Study Program of University PGRI of Semarang and Semarang Sultan Agung Islamic University in 2015 and 2016 school year.

\section{Research Design}

The research design used in this study is a Borg and Gall model [16] with 10 stages, namely (1) the potential and problems, (2) Data collection, (3) the design of the product, (4) Validation of design, (5) Revision of design, (6) product trial, next in the second year are implemented stage 7-10 namely (7) Revision of design (8) trial usage (9) products revision, (10) of mass-production (Figure 1).

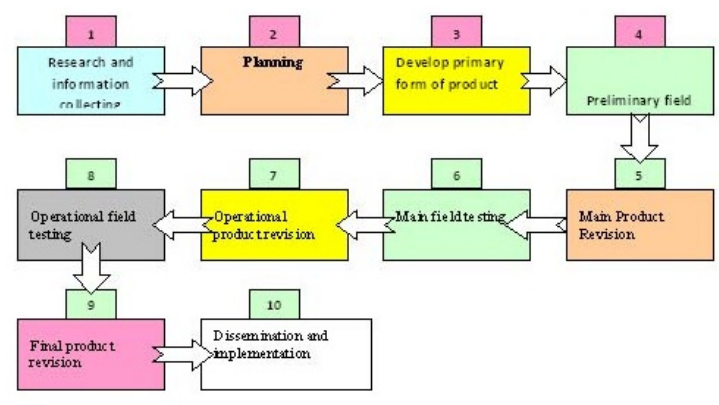

Figure 1: $\mathrm{R}$ and $\mathrm{D}$ procedure of Borg and Gall model.

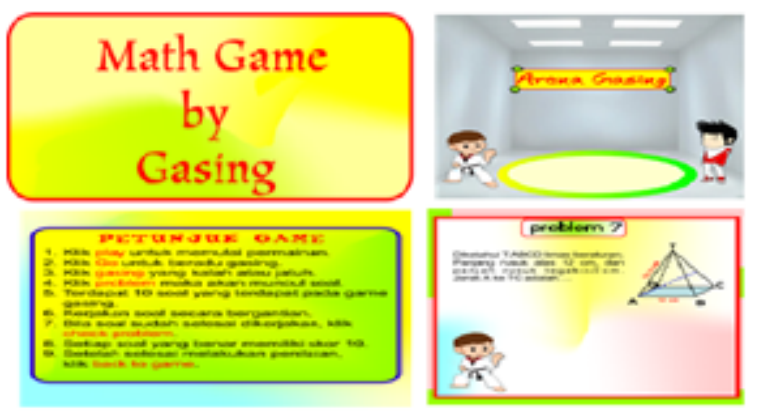

Figure 2: Design of digital math game. 


\section{Result and Discussion}

\section{Media design of digital math game}

It have produced digital design of math games systematically using Adobe Flash CS 6 and Corel Draw, instrumental music, and ratings so that the product is more refined and tidy, then local wisdom taken were from Central Java games (Figure 2).

\section{Result of expert validation}

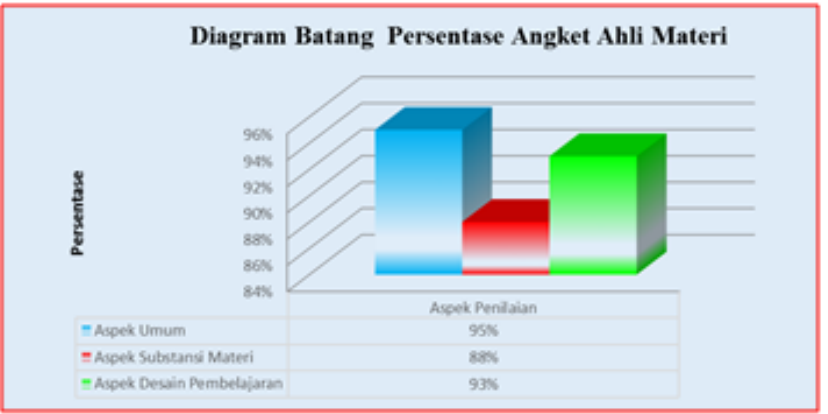

Figure 3: Validation result of material expert.

The results of feasibility by material validation shows the percentage of the general aspects are 95\% and 90\%, the aspect of material substance are $88 \%$ and $90 \%$, aspects of learning design are $93 \%$ and $91 \%$. From the calculation of the level of achievement of learning media obtained a percentage of $91 \%$. A percentage that has been obtained is then transformed into a sentence which is qualitative. To be able to give meaning and decision-making is used precision as an indicator of the success of expert validation of learning materials. The results showed that the indicator percentage between $81 \%-100 \%$ on the criterion of "Very Good". So that the test from material experts the percentage is successful or feasible (Figure 3 and Figure 4).

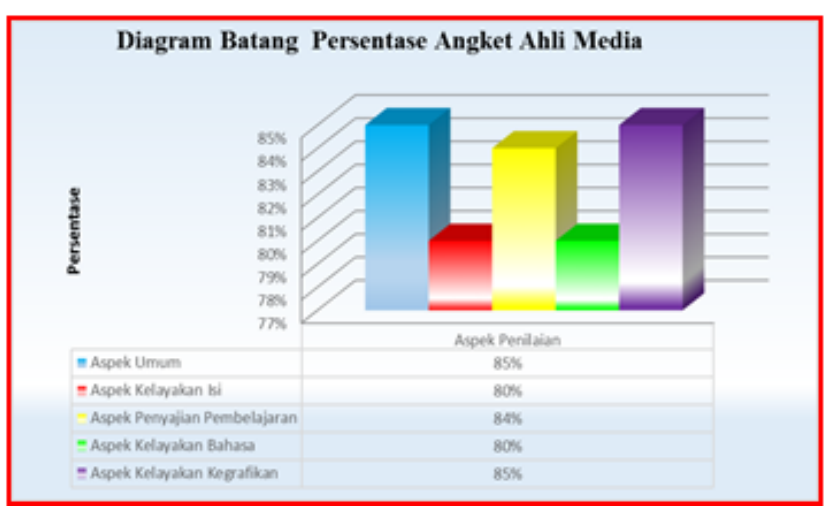

Figure 4: Validation result of media expert.

The results of the feasibility of media validation shows the percentage of general aspects $95 \%$ and $85 \%$, feasibility aspects of the content of $80 \%$ and $80 \%$, aspects of the presentation of learning $84 \%$ and $84 \%$, feasibility aspects of language $80 \%$ and $80 \%$, the feasibility aspects of graphs $80 \%$ and $85 \%$, From the calculation of the level of achievement of learning media obtained a percentage of $81 \%$. A percentage that has been obtained is then transformed into a sentence which is qualitative. To be able to give meaning and decision-making is used precision as an indicator of the success of expert validation of learning media. The results showed that the indicator percentage between $81 \%-100 \%$ on the criterion of "Very Good". So the test of media expert of the percentage is successful or feasible.

Based on the results the feasibility percentage of media validation and validation of the material showed a range between $81 \%-100 \%$ so that the Digital Math Game media with ethnomathematics models is classified as very well criteria.

\section{The process of mathematics learning in University PGRI of Semarang and Semarang Sultan Agung Islamic University}

The reason for choosing students of mathematics education study program of University PGRI of Semarang (UPGRIS) and Semarang Sultan Agung Islamic University (UNISSULA) is because both private universities and represent an element of general and religion campus in Semarang, then both campuses have modern learning facilities so hopefully learning with digital products of math game is able to be applied and improve student learning outcomes (Figure 5 and Figure $6)$.

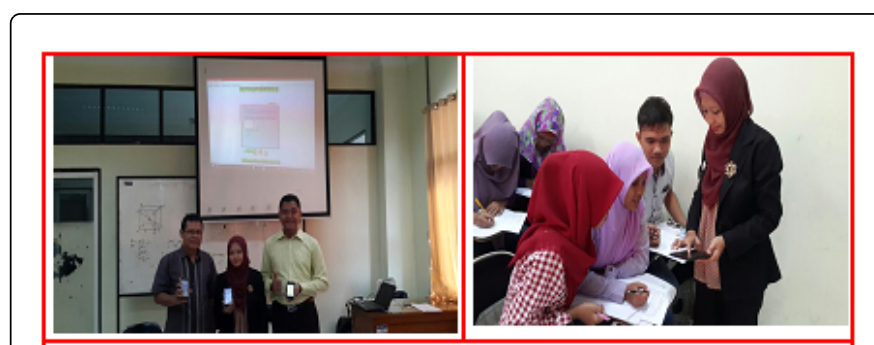

Figure 5: Introduction Process to students of University PGRI of Semarang about Digital Math Game Product.

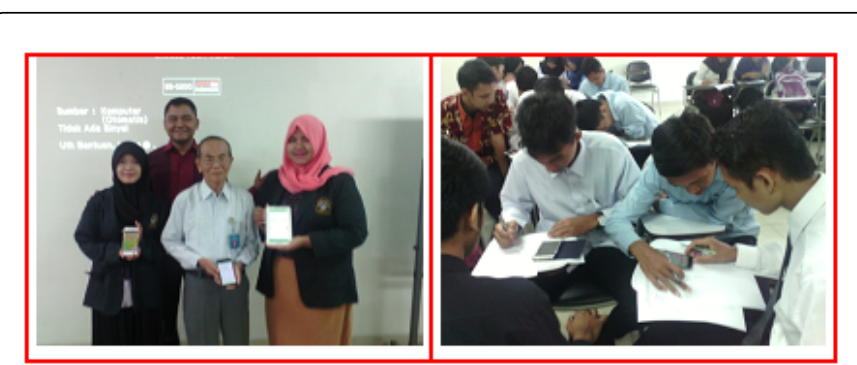

Figure 6: Introduction Process to students of Semarang Sultan Agung Islamic University about Digital Math Game Product.

\section{Students response towards digital math game product}

Student of mathematics education study program of University PGRI of Semarang (UPGRIS) and Semarang Sultan Agung Islamic University (UNISSULA) has provided an excellent response to all media products that are applied in teaching of high school math courses covering material of geometry, statistics, odds, algebra, row, and trigonometry with good categories (Figure 7). 


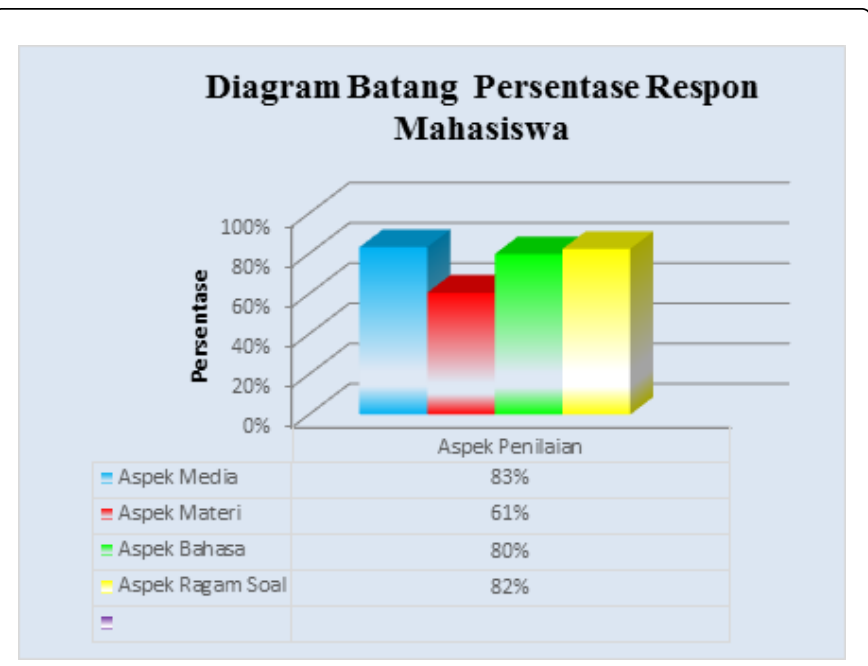

Figure 7: Result of students' response towards digital math game product.

\section{Final score of math test in University PGRI of Semarang (UPGRIS) and Semarang Sultan Agung Islamic University (UNISSULA)}

Once the product is declared valid and got a good response by the users then do the final test against students of mathematics education program study of University PGRI of Semarang (UPGRIS) and Semarang Sultan Agung Islamic University (UNISSULA) with 6 subject matters with an average of 84.5 and 83,33 . It concluded that digital math game products will increase student learning outcomes (Figure 8 and Figure 9).

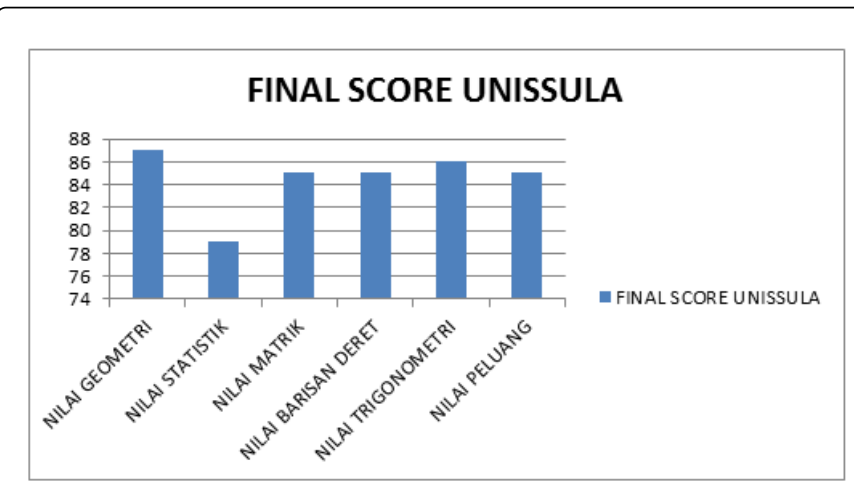

Figure 8: Final test result of students of UNISSULA towards digital math game product.

Finally, this research supported Buchori and Susanto [17] showed development of mobile media -based learning software classpad casio at flat geometry course in higher education is more effectiv than learning with direct instruction, and then Waluya [18] showed the development of innovation learning and teaching materials based ethnomatematika can make strengthen the character of the student, correlation with digital game Papastergiou [19] showed if Digital Game-Based Learning in high school Computer Science education can give more Impact on educational effectiveness and student motivation, so Swearingen [20] same showed Effect Of Digital Game Based Learning On Ninth Grade Students Mathematics Achievement at Oklahoma University can make student achivemement, and the and Karafili and Stana [21] showed "The Learning of Mathematics Supported by GBL - A Novelty for Albanian Preschool System”, can make student at preschool happy and interest to learning at school with GBL[22-26].

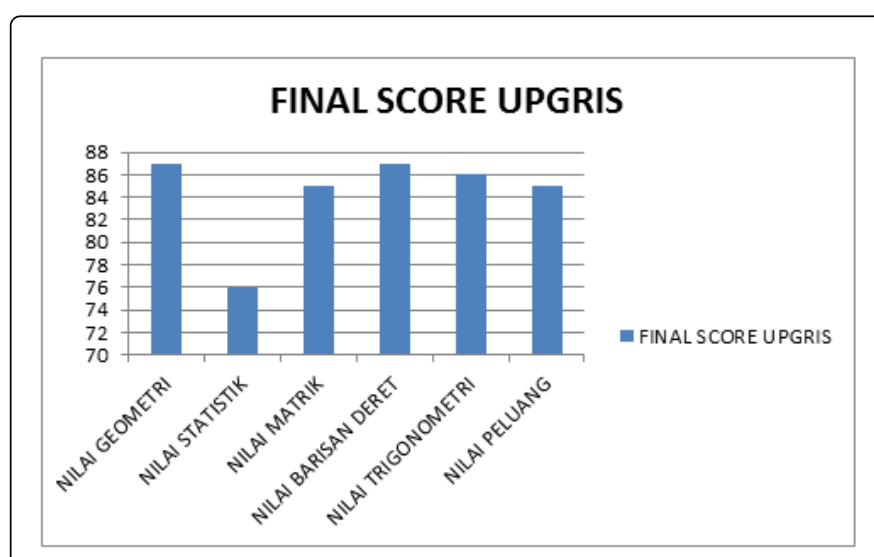

Figure 9: Final test result of students of UPGRIS towards digital math game product.

\section{Conclusion and Suggestion}

Based on the formulation of the problem, the research data analysis and discussion of the problem, it can be summed up as follows:

\section{Conclusion}

- The final product has been produced that is digital math game with the ethnomathematics mo Buchori and Susanto [17] "Development of Mobile Media -Based Learning Software CLASSPAD Casio At Flat Geometry Course in Higher Education del with javanese local wisdom based digitally via mobile phones and computers that are eligible for use in the process of teaching in high school math courses in college.

- Media of digital math game with javanese local wisdom based is preferred by students of University PGRI of Semarang and Semarang Sultan Agung Islamic University to support the learning of high school math.

\section{Suggestion}

- It is expected that digital math game products are widely used for all mathematics education study program in Central Java

- It is expected that digital math games products become the flagship product in the high school and higher education level mathematics learning

\section{References}

1. Ayad K, Rigas D (2010) Multi-modal game based learning: satisfaction and users achievement approach. Stevens Point, Wisconsin, USA.

2. Wena (2009) Contemporary innovative learning strategies: An overview of operations publisher conceptual earth literacy, Jakarta. 
Citation: Buchori A, Sudargo, Rahmawati ND, Budiman MA (2016) Digital Media Development of Math Game with Ethnomathematics Model Based on Javanese Local Wisdom in Higher Education. Arts Social Sci J 7: 210. doi:10.4172/2151-6200.1000210

Page 5 of 5

3. De Freitas S, Roberts G (2006) Does distance e-learning work? A comparison between distance and face-to-face learners using e-learning materials. Association of Learning Technology Journal 11: 69-87.

4. Burguillo JC (2010) Using game theory and competition-based learning to stimulate student motivation and performance. Computers and Education 55: 566-575.

5. Muhammad N (2011) Fundamental understanding Digital Culture. Digital journal/Digital game.

6. Cheng H, Li M, Wu J, Carlson A, Hwang KC et al. (2012) A Viscoelastic Model for the Rate Effect in Transfer Printing. ASME Journal of Applied Mechanics.

7. Ebner M, Holzinger A (2002) e-Learning in civil engineering: the experience applied to a lecture course in structural concrete. Scientific Journal of Applied Information Technology.

8. Yee WA, Zah W, Rosnaini M, Roselan B (2009) Form one students engagement with computer games and its effect on their academic achievement in a Malaysian secondary school. Comput Educ 53: 1082-1091.

9. Garris RA, Driskell JE (2002) Games, Motivation, and Learning: A Research and Practice Model, Simul. Gaming 33: 441-467.

10. Iacovides J, Aczel E, Scanlon J, Taylor, Woods W (2011) Motivation, Engagement and Learning through Digital Games. Int J Virtual Pers Learn Environ 2: 1-16.

11. Panoutsopoulos H, Sampson DG (2012) A Study on Exploiting Commercial Digital Games into School Context. Educ Technol Soc 15: 15-27.

12. Kebritch, Hirumi A (2008) Examining the pedagogical foundations of modern educational computer games. Comput Educ 51: 1729-1743.

13. Shirley (1995) Using ethnomathematics to find multicultural mathematical connection. PA House and AFC Oxford.

14. Bishop (1994) Cultural conflict in mathematics education: developing a research agenda, for the learning mathematics.
15. Tuckman BW, Harper BE (2012) Conducting Educational Research. Rowman and Littlefield Publishers, Inc., Lanham.

16. Borg WR, Gall MD (2001) Educational Research. Logham C.A, New York.

17. Buchori, Susanto (2011) Development of mobile media -based learning software CLASSPAD Casio at flat geometry course in higher education. Journal MIPMIPA Unhalu.

18. Waluya B (2013) The development of innovation-based learning and teaching materials ethnomatematika to strengthen the character of the student. Kreano UNNES Semarang Journal.

19. Papastergiou (2009) Digital Game-Based Learning in high school Computer Science education: Impact on educational effectiveness and student motivation. Comput Educ 52: 1-12.

20. Swearingen (2011) Effect of digital game based learning on ninth grade students' Mathematics Achievement. Oklahoma University.

21. Karafili, Stana A (2012) The Learning of Mathematics Supported by GBLA Novelty for Albanian Preschool System. J Educ Soc Res 2: 297-306.

22. Holzinger A, Kosec P, Schwantzer G, Debevc M, Hofmann-Wellenhof R et al. (2007) Design and development of a mobile computer application to reengineer workflows in the hospital and the methodology to evaluate its effectiveness. Journal of biomedical informatics 44: 968-977.

23. Muhibbin S (2008) Psychology in Education with a New Approach . Youth Rosdakarya, Bandung.

24. Jauhar SM (2008) Learning Material Development Guide. Publisher mone.

25. Robson B, Harris R (2005) Hauora: Maori standards of Health IV-A study of the years 2000-2005. University of Otago, Wellington.

26. Safari (2003) Evaluation of learning. MONE Directorate General of Primary and Secondary Education. 